\title{
Pre endodontik build-up dengan teknik canal projection pada gigi insisif lateral rahang atas disertai kerusakan mahkota yang sangat luas
}

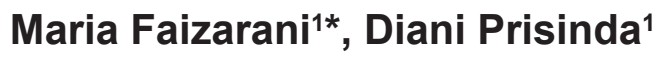 \\ ${ }^{1}$ Departemen Konservasi Gigi, Fakultas Kedokteran Gigi Universitas Padjadjaran, Indonesia
}

*Korespondensi: maria18012@mail.unpad.ac.id

Submisi: 21 September 2020; Penerimaan: 30 Agustus 2021; Publikasi online: 31 Agustus 2021

DOI: $\underline{10.24198 / j \mathrm{~kg} . v 33 i 2.29521}$

\begin{abstract}
ABSTRAK
Pendahuluan: Gigi dengan kerusakan mahkota yang sangat luas sering menimbulkan masalah dalam perawatan endodontik seperti kesulitan dalam penempatan klem rubber dam sehingga isolasi yang kurang memadai serta kemungkinan terjadinya kebocoran koronal yang mengakibatkan risiko kegagalan perawatan endodontik. Gigi dengan keadaan tersebut membutuhkan restorasi sementara pre endodontic agar dapat dilakukan isolasi yang memadai, penempatan klem yang efektif selama perawatan dan pemulihan estetik sementara selama perawatan saluran akar. Tujuan laporan kasus ini untuk menjelaskan pembuatan pre endodontic build-up menggunakan alat tip plastik sekali pakai selama perawatan saluran akar pada gigi insisif rahang atas dengan kerusakan mahkota yang sangat luas. Laporan kasus: Pasien perempuan berusia 53 tahun datang ke Klinik Konservasi Gigi RSGM Unpad dengan keluhan gigi seri rahang atas kiri patah saat makan. Gigi tersebut pernah dirawat saluran akar satu tahun yang lalu namun tidak selesai. Pemeriksaan klinis menunjukkan kehilangan mahkota sampai batas servikal, dan terdapat gambaran radiolusen yang difus di area periapikal. Diagnosis berdasarkan American Association of Endodontics (AAE) adalah previously initiated therapy disertai periodontitis apikalis asimptomatik. Pembuatan pre endodontic build-up dengan teknik canal projection dilakukan untuk mendapatkan isolasi sekaligus sebagai restorasi sementara dan dilanjutkan dengan perawatan saluran akar dan pembuatan mahkota all porcelain dengan fiber post. Simpulan: Pembuatan pre endodontic build-up menggunakan teknik canal projection berhasil dilakukan selama perawatan saluran akar gigi insisif lateral kiri atas dengan kerusakan mahkota yang sangat luas. Pre endodontic build-up dengan teknik canal projection pada kasus ini dapat memberikan isolasi yang memadai, memudahkan penempatan klem rubber dam serta memberikan pemulihan estetik yang baik selama periode antar kunjungan.
\end{abstract}

Kata kunci: Mahkota gigi; gigi seri rahang atas kiri; endodontik; saluran akar, mahkota gigi.

\section{Pre endodontic build-up with canal projection technique on maxillary lateral incisors with extensive crown damage}

\section{ABSTRACT}

Introduction: Extensive crown damage often causes problems in endodontic treatment, such as difficulty placing rubber dam clamps, resulting in inadequate isolation and the possibility of coronal leakage, which results in treatment failure risk. This condition requires pre-endodontic temporary restorations to provide adequate isolation, effective clamping during treatment, and temporary aesthetic restoration during root canal treatment. The purpose of this case report was to describe the fabrication of a pre-endodontic build-up using a disposable plastic tip device during root canal treatment of a maxillary incisor with extensive crown damage. Case report: A 53-year-old female patient came to the Conservative Dentistry Clinic of Universitas Padjadjaran Dental Hospital to complain of a fractured left maxillary incisor that occurred while eating. The tooth had a root canal treatment one year prior but was not completed. Clinical examination revealed crown loss to the cervical margin and a diffuse radiolucent appearance in the periapical area. According to the American Association of Endodontics (AAE), the diagnosis was previously initiated therapy with asymptomatic apical periodontitis. Therefore, the pre-endodontic build-up using the canal projection technique was performed to obtain isolation and temporary restoration, continued with root canal treatment and the manufacture of an all-porcelain crown with fibre post. Conclusions: The pre-endodontic buildup with canal projection technique has been successfully performed during root canal treatment of the maxillary left lateral incisor with extensive crown damage. Pre-endodontic build-up with canal projection technique can provide adequate isolation, facilitate the placement of rubber dam clamps, and provide good aesthetic recovery during the period between visits.

Keywords: Dental crowns; maxillary lateral incisors; endodontic; root canal, dental crown. 


\section{PENDAHULUAN}

Gigi dengan kerusakan pada mahkota yang sangat luas atau dengan fraktur di bagian mahkota gigi (bagian koronal) disertai dengan terbukanya ruang pulpa seringkali menimbulkan masalah selama perawatan saluran akar. ${ }^{1,2,3,4,5,6,6,7,8}$ Masalah yang sering ditemui yaitu saat isolasi pada perawatan saluran akar karena kesulitan dalam penempatan klem rubber dam, sehingga dengan sisa jaringan yang minimal dapat meningkatkan risiko fraktur koronal maupun radikuler pada periode antar kunjungan. . $^{1,2,3,4,5}$

Restorasi pre endodontic dianjurkan untuk membantu mendapatkan kondisi aseptik selama prosedur perawatan saluran akar, mempertahankan akses dan bentuk saluran dari orifis hingga cavosurface. . $^{1,2,3,4,5}$ Bentuk restorasi ini akan menyediakan coronal seal yang baik, serta menjaga dan mempertahankan integritas struktur gigi yang tersisa hingga perawatan saluran akar selesai dan dilakukan pembuatan restorasi akhir yang adekuat. ${ }^{1,23,4,5}$ Upaya untuk mempertahankan akses saluran akar pada gigi dengan kerusakan mahkota yang sangat luas selama prosedur perawatan saluran akar merupakan tantangan yang besar bagi operator. Hal ini dapat dilakukan dengan pembuatan restorasi pre endodontic dengan teknik canal projection. ${ }^{1,3,4,5}$

Teknik canal projection merupakan suatu teknik yang digunakan untuk memproyeksikan kanal orifis dari lantai kamar pulpa hingga ke permukaan kavitas secara langsung pada gigi yang dirawat saluran akar dengan kerusakan mahkota yang sangat luas. . $^{1,3,45}$ Teknik ini awalnya diperkenalkan oleh Gerald N Glickmann dan Roberta Pillegi dengan alatnya ProjectorEndodontic Instrument Guidance System (PEIGS) yang berfungsi untuk mempertahankan patensi kanal. Alat lain yang dapat digunakan selain PEIGS untuk memproyeksikan kanal dari orifis diantaranya yaitu dengan menggunakan tip plastic, jarum suntik dan gutta percha. Pembuatan restorasi sementara pre endodontic pada kasus ini dibuat dengan cara yang sederhana menggunakan bahan yang tersedia di klinik, yaitu tip plastik sekali pakai, sebagai metode yang efisien untuk menangani kasus kehilangan struktur mahkota yang cukup kompleks. . $^{1,3,4,5}$
Kegagalan pada perawatan saluran akar erat hubungannya dengan restorasi yang tidak adekuat. ${ }^{2,5,9}$ Saunders dan Saunders pada tahun 2014 pertama kali mengemukakan kebocoran koronal merupakan penyebab yang dapat mengakibatkan kegagalan perawatan saluran akar. Pada penelitian yang dilakukan oleh Tronstad et al tahun 2000, gigi dengan perawatan saluran akar yang baik dan diikuti dengan restorasi yang adekuat menunjukkan tingkat keberhasilan tertinggi (81\%) dibandingkan dengan gigi dengan perawatan saluran akar yang baik dan diikuti dengan restorasi yang buruk dengan tingkat kesuksesan menurun $71 \%{ }^{6}$ Restorasi pasca perawatan saluran akar yang baik harus dapat memberikan coronal seal yang adekuat, dapat memberikan perlindungan bagi struktur gigi yang tersisa, dapat mengembalikan bentuk gigi serta fungsi oklusi dan estetikanya. ${ }^{2,9,10,11}$ Mahkota penuh merupakan pilihan restorasi pada gigi yang mengalami kehilangan mahkota yang luas karena karies, fraktur, atau prosedur endodontik. Restorasi dengan pasak dan inti dibuat terutama pada gigi yang telah kehilangan banyak struktur mahkota sehingga membutuhkan retensi tambahan hingga ke saluran akar. ${ }^{10,11}$

Kerusakan mahkota sangat luas pada kasus ini menyulitkan klinisi saat melakukan perawatan saluran akar dalam isolasi terutama saat penempatan klem rubber dam. Keadaan ini dapat meningkatkan risiko fraktur jaringan yang tersisa dan kegagalan dalam perawatan saluran akar. Tujuan laporan kasus ini adalah untuk melaporkan tahapan pembuatan restorasi pre endodontic buildup dengan teknik canal projection pada gigi insisif lateral rahang atas dengan kerusakan mahkota yang sangat luas.

\section{LAPORAN KASUS}

Pasien perempuan usia 53 tahun datang ke Klinik PPDGS Konservasi Gigi RSGM Unpad mengeluhkan gigi depan rahang atas kiri patah saat makan kerupuk, tidak ada keluhan sakit maupun riwayat bengkak. Gigi tersebut pernah dirawat saluran akar sekitar satu tahun yang lalu namun pasien tidak menyelesaikan perawatannya. Pasien ingin giginya segera dirawat karena mengganggu 
penampilan dan mengurangi rasa percaya diri saat mengajar. Pasien mengaku tidak memiliki riwayat penyakit sistemik dan tidak memiliki alergi.

Pemeriksaan ekstra oral terlihat wajah simetris, kelenjar getah bening tidak ada pembengkakan, pemeriksaan sendi temporomandibular tidak terdapat kliking dan krepitasi. Tekanan darah 120/80 mmHg, pernafasan $25 x /$ menit dan nadi $86 x /$ menit. Riwayat penyakit diabetes melitus, penyakit jantung, hepatitis dan alergi disangkal. Pemeriksaan intra oral gigi 22 menunjukkan kehilangan mahkota sampai batas servikal dengan pulpa yang terbuka dan sisa struktur mahkota yang minimal. Tes vitalitas menunjukkan hasil negatif, tidak terdapat kepekaan terhadap tes perkusi dan tekan, tidak terdapat mobility, tidak terdapat kelainan saat dilakukan tes palpasi, dan tidak tampak adanya fraktur pada jaringan gigi yang tersisa saat dilakukan tes transluminasi. Kebersihan mulut penderita sedang, gingiva berwarna pink dengan tekstur stippling, bentuk interdental papilla lancip, konsistensi kenyal (Gambar 1A dan B). Hasil pemeriksaan radiografis gigi 22 terlihat kehilangan seluruh mahkota dan radiolusen mencapai ruang pulpa, saluran akar lurus, radiopak pada orifis saluran akar seperti bahan pengisi saluran akar, pelebaran ligamen periodontal pada sepertiga apikal dan lamina dura yang terputus di sepertiga apikal, radiolusensi berbatas tidak jelas di daerah periapikal dan jaringan pendukung gigi cukup adekuat (Gambar 1C).

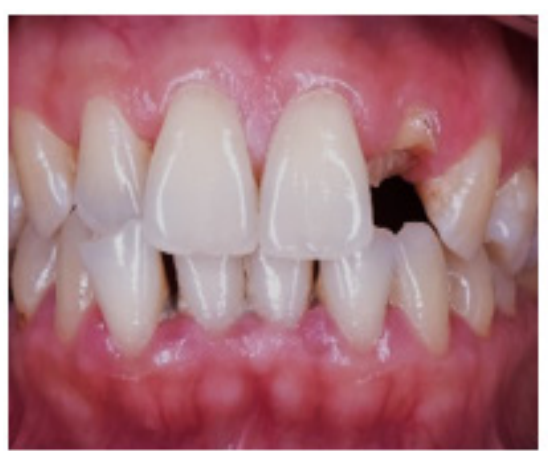

A

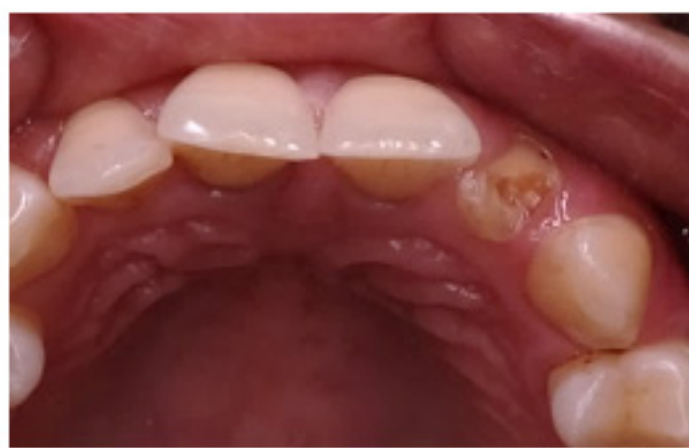

B

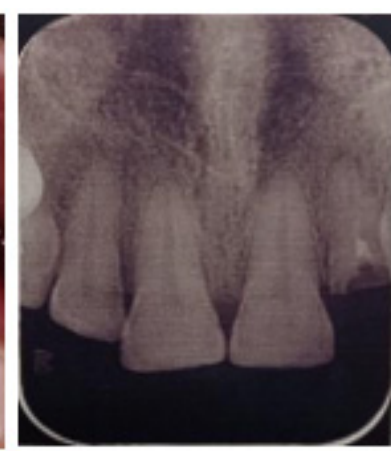

C

Gambar 1. Gambaran klinis gigi 22 sebelum dilakukan perawatan: A. Tampak labial; B. Tampak insisal; C. Gambaran radiografis periapikal gigi 22 sebelum dilakukan perawatan (Sumber: Dokumentasi pribadi)

Diagnosis gigi 22 berdasarkan klasifikasi American Association of Endodontists tahun 2013 adalah previously initiated therapy dengan periodontitis apikalis asimptomatik. Rencana perawatan yang akan dilakukan yaitu pembuatan restorasi sementara pre endodontic build-up dengan teknik canal projection, perawatan saluran akar pada gigi 22 dan follow-up restorasi mahkota all-porcelain dengan menggunakan fiber post. Prognosis kasus baik, posisi gigi tidak menyulitkan untuk dilakukan perawatan, sisa struktur jaringan keras gigi masih memungkinkan untuk dilakukan pembuatan mahkota sementara, pasien kooperatif, serta tidak ada kelainan sistemik.

Kunjungan pertama, dilakukan anamnesis dan pengambilan dokumentasi awal secara lengkap, kemudian dilakukan pemeriksaan subjektif, objektif, penentuan diagnosis dan rencana perawatan. Pasien diberikan informasi mengenai keadaan giginya dan seluruh tindakan perawatan yang akan dilakukan serta komplikasi yang mungkin terjadi. Sebelum tindakan perawatan saluran akar pada gigi 22, terlebih dahulu dilakukan pencetakan pada rahang atas dan rahang bawah untuk pembuatan restorasi sementara pre endodontic build-up menggunakan teknik canal projection. Setelah didapatkan model kerja dari cetakan tersebut, dilakukan wax-up gigi 22 dengan menggunakan mock-up wax putih pada model (Gambar 2A), selanjutnya dibuat silicone index dengan menggunakan putty material pada bagian palatal dan insisal dari gigi 21 sampai 23 , kemudian dilakukan pencocokan warna gigi dengan shade guide dan didapatkan warna A2 (Gambar 2A dan C).

Pembuatan restorasi pre endodontic buildup dengan teknik canal projection dimulai dengan melakukan isolasi dengan rubber dam. Karies dan bagian yang lunak pada gigi 22 dibersihkan. Restorasi pre endodontic build-up dengan teknik 


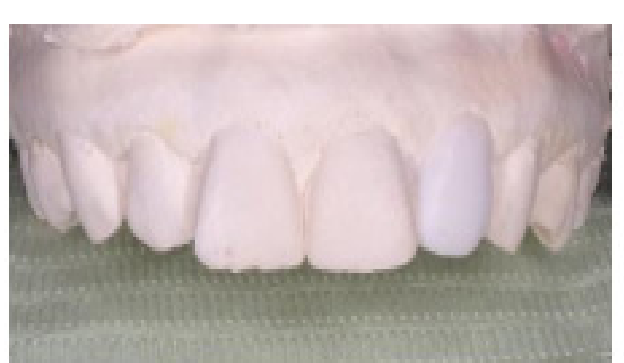

A

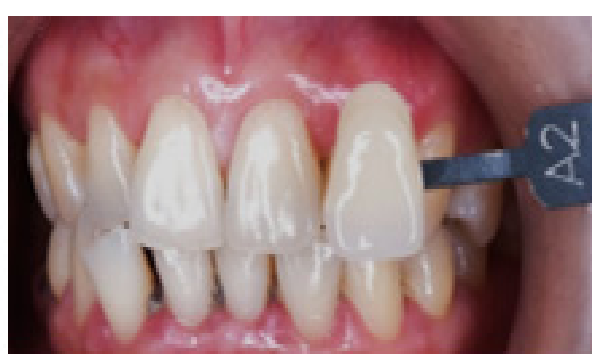

B

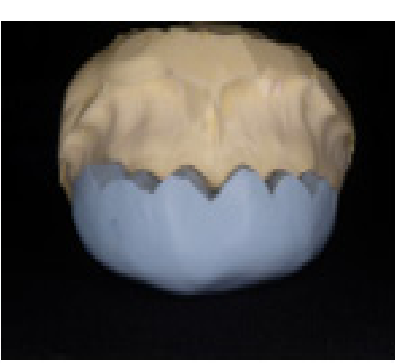

C

Gambar 2. A. Penentuan warna dengan bantuan shade guide; B. Pembuatan wax-up gigi 22 pada model; C. Silicon index dengan bahan putty (Sumber: Dokumentasi pribadi)

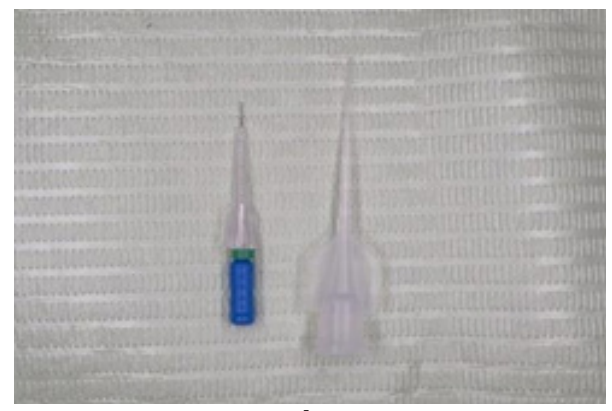

A

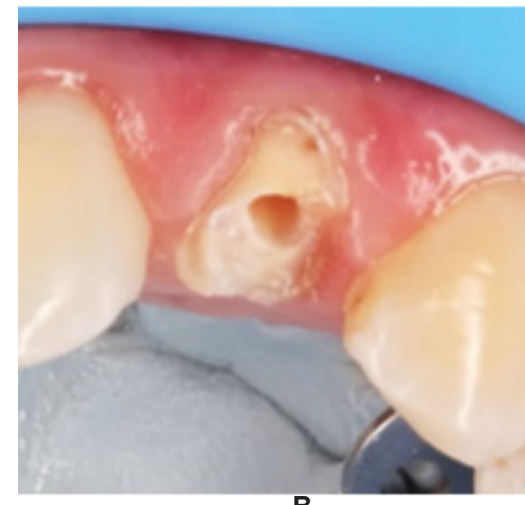

B

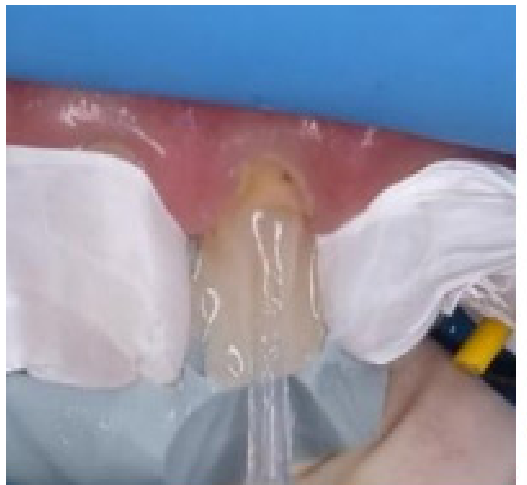

$E$

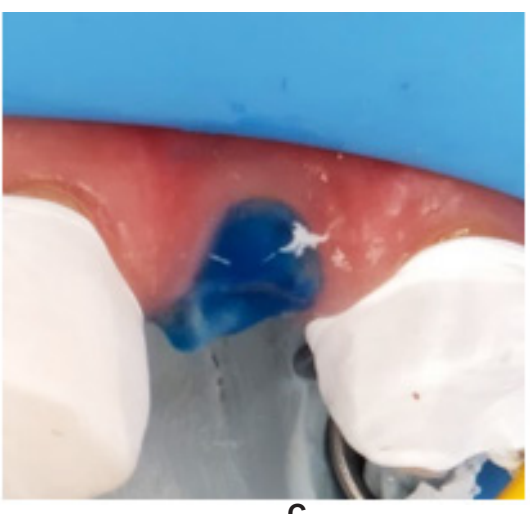

C

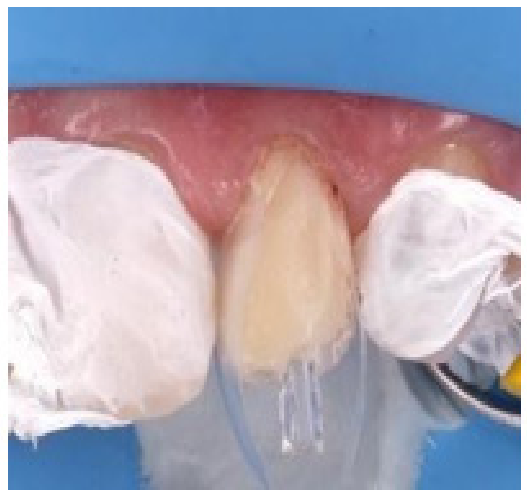

$F$
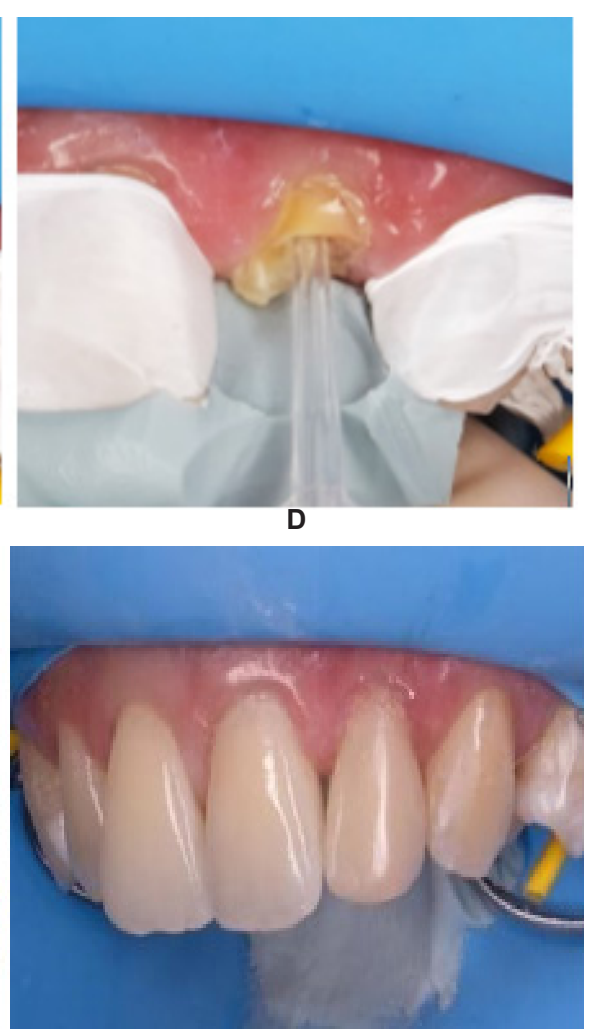

G

Gambar 3 A. Alat pembuat canal projection dengan tip Calcipex; B. Isolasi menggunakan rubber dam; C. Aplikasi asam

fosforik 37\%;D. penempatan canal projection dan aplikasi bonding agent; E. pembentukan cangkang palatal dengan bantuan silicone index; F Dinding proksimal dibuat dengan bantuan countoured matrix band dan pembuatan bagian labial secara incremental; G. Hasil setelah dilakukan finishing dan polishing (Sumber: Dokumentasi pribadi)

canal projection menggunakan tip plastic disposable dari Calcypex II (bahan medikamen kalsium hidroksida) (Gambar 3A). Orifis dilebarkan dengan menggunakan $\mathrm{K}$-file \# 30, kemudian permukaan email dan dentin yang terekspos diaplikasikan asam fosforik $37 \%$ selama 20 detik lalu dibilas dan dikeringkan (Gambar 3C). K-File ditempatkan pada proyektor plastik dan ujung file keluar sekitar 
5-8 $\mathrm{mm}$ dari projector. Ukuran file disesuaikan dengan besar orifis gigi 22, kemudian proyektor dimasukkan ke dalam orifis dan diaplikasikan bonding Single Bond Universal (3M Espe, USA) (Gambar 3D). Build-up restorasi menggunakan komposit NanoHybrid Filtex Z350 XT (3M Espe, USA) yang diawali pembuatan cangkang palatal dengan bantuan silicone index (Gambar 3E). Dinding proksimal dibuat dengan bantuan contoured matrix band (Gambar 3F). Bagian labial dan insisal dibuat secara incremental dan masingmasing bagian dilakukan penyinaran selama 20 detik, setelah itu canal projection diangkat. Kontur anatomis dibentuk menggunakan contouring disk kemudian dilakukan prosedur finishing dengan menggunakan bur diamond halus dan polishing dengan polishing disk dan strip. Restorasi pre endodontic dengan akses dari cavosurface ke saluran akar telah selesai dibuat (Gambar 3G).

Perawatan saluran akar diawali dengan glide path menggunakan K-file no 20 dan panjang kerja diukur menggunakan apex locator yang menunjukkan panjang kerja $21 \mathrm{~mm}$. Preparasi saluran akar dilakukan menggunakan teknik crown down dengan menggunakan rotary instrument protaper next (Dentsply Maillefer, Switzerland) hingga file $X 4$. Irigasi dilakukan setiap pergantian file dengan menggunakan $\mathrm{NaOCl} 5.25 \%$ dan aquadest. Irigasi diakhiri dengan EDTA 17\%, chlorhexidine $2 \%$ dengan akuades pada setiap pergantian irigasi. Pada saat irigasi, cairan yang terdapat di saluran akar diagitasi menggunakan Endoactivator (Dentsply Maillefer, USA). Saluran akar kemudian dikeringkan menggunakan paper point dan dilakukan pemberian medikasi intrakanal kalsium hidroksida (Calcipex II, Noppon Shika
Yakuhin Co., Ltd, Japan) serta ditutup tambalan sementara (Caviton, GC Corporation Tokyo, Japan). Kunjungan berikutnya pasien datang 14 hari kemudian, gigi 21 dievaluasi dan menyatakan tidak ada keluhan, tes perkusi dan tekan negatif. Gigi kemudian diisolasi menggunakan rubber dam dan tambalan sementara dibuka. Medikamen kalsium hidroksida di dalam saluran akar dibersihkan dengan larutan irigasi. Saluran akar kemudian dikeringkan menggunakan paper point.

Pengisian saluran akar diawali dengan uji coba gutta percha point menggunakan gutta percha 40/06 dan dilakukan konfirmasi menggunakan radiografis (Gambar 4A). Pengisian saluran akar dilakukan dengan teknik kondensasi lateral menggunakan sealer berbahan resin $(\mathrm{AH}$ Plus, Dentsply DeTrey, Germany). Gutta-percha dipotong sampai sampai $2 \mathrm{~mm}$ di bawah orifis, kavitas dibersihkan dari sisa sealer, kemudian ditutup dengan semen glass ionomer (Fuji IX, GC Japan) sebagai coronal seal kemudian ditutup dengan tambalan sementara dan kembali dilakukan pemeriksaan radiografi untuk mengkonfirmas hasil obturasi yang hermetis (Gambar 4B). Pasien datang kontrol 1 minggu kemudian, tidak terdapat keluhan pada gigi 22, tes perkusi dan tekan negatif, serta tidak ada kegoyangan. Pemeriksaan radiografi kontrol pasca obturasi menunjukkan tidak terdapat kelainan dan gambaran radiolusen di area periapikal mulai berkurang (Gambar $4 \mathrm{C}$ ).

Perawatan dilanjutkan dengan preparasi untuk pemasangan pasak fiber prefabricated (Dentolic Itena, France) dengan menggunakan twist drill (Dentolic Itena, France). Setelah kavitas dan restorasi lama dibersihkan, dilakukan pengurangan gutta percha dua pertiga saluran

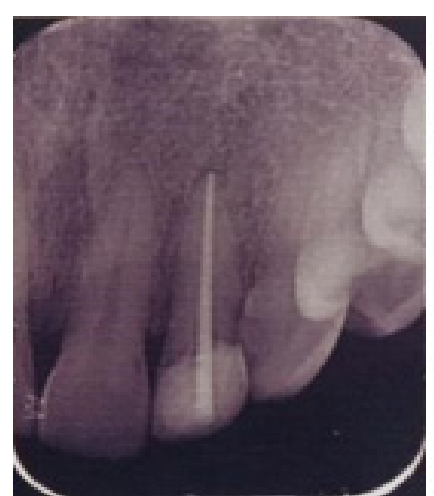

A

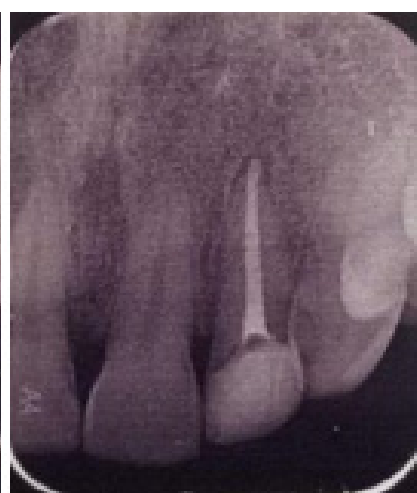

B

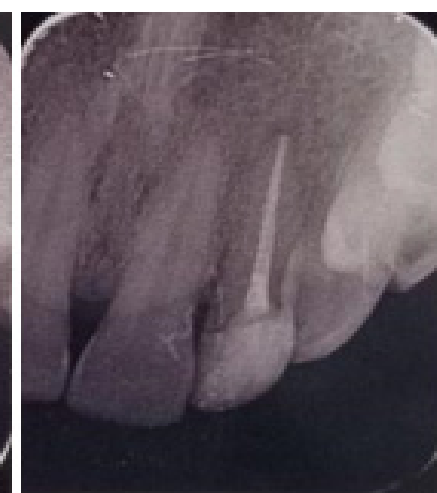

C

Gambar 4. A.Radiografi periapikal trial obturasi saluran akar gigi 21; B. Radiografi periapikal setelah obturasi saluran akar gigi 21; C. Gambaran radiografis periapikal kontrol pasca obturasi. (Sumber: Dokumentasi pribadi) 
akar dan menyisakan kira-kira $5 \mathrm{~mm}$ gutta percha di ujung apikal akar. Gutta percha dikurangi menggunakan gates gliden drill dengan diameter sama dengan diameter saluran akar (Gambar 5A). Foto radiografi dilakukan untuk memastikan gutta percha sudah bersih (Gambar 5D).

Pasak selanjutnya disementasi dengan menggunakan dual curing core dan resin cement (Paracore Coltene, Switzerland). Pasak fiber di etsa, dibilas, dikeringkan dan diolesi silane kemudian didiamkan 90 detik. Dinding saluran akar diaplikasikan etsa asam fosfat $37 \%$ selama 15 detik kemudian dibilas dengan aquades steril hingga bersih. Dinding saluran akar diaplikasikan bonding dan kelebihannya diambil dengan menggunakan paper point kecil. Setelah bonding merata, dilakukan penyinaran selama 20 detik dan dilanjutkan dengan injeksi semen resin dan insersi pasak (Gambar 5A-C). Pengerasan semen resin dibantu dengan tambahan penyinaran selama 20 detik, kemudian dilakukan konfirmasi hasil sementasi pasak dengan foto radiografi (Gambar 5E).

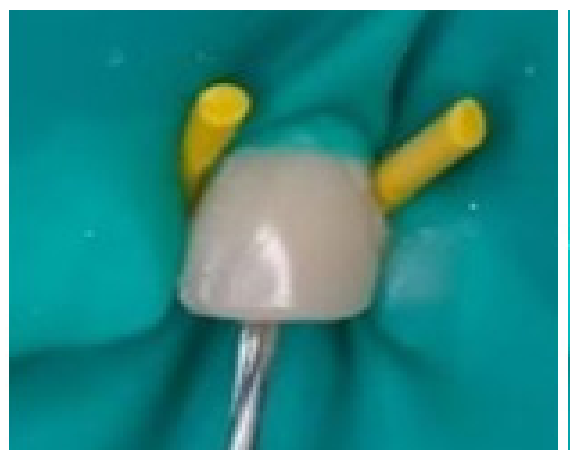

A

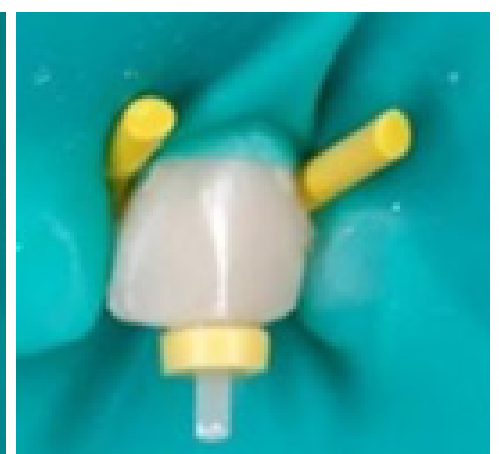

B

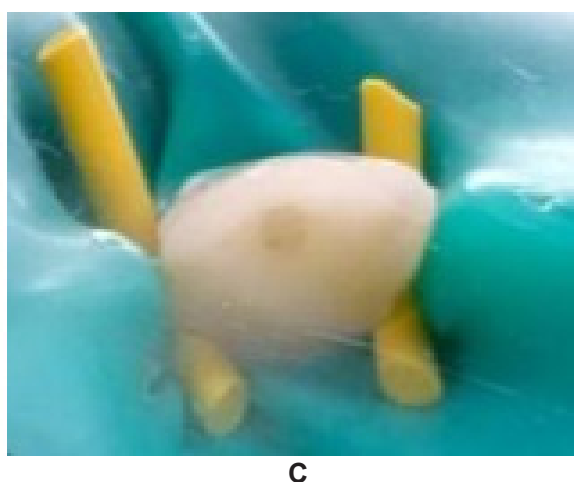

C
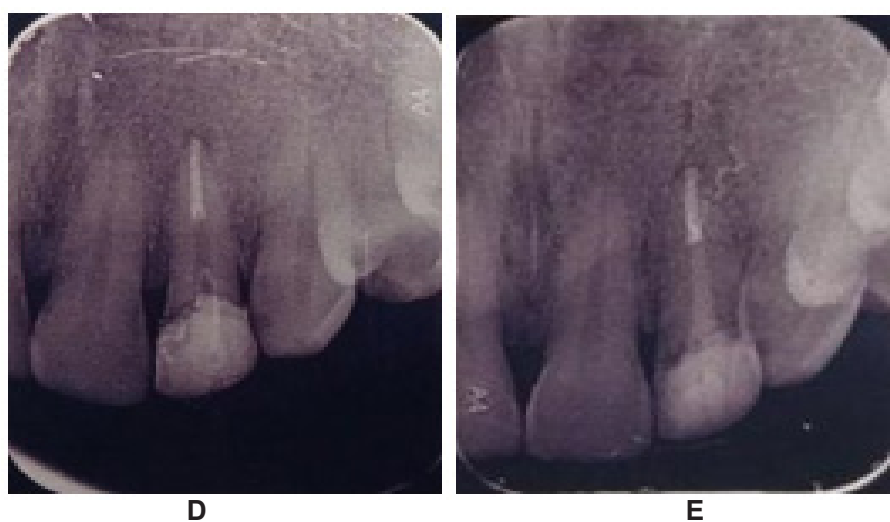

Gambar 5. A. Preparasi saluran akar; B. Uji coba pasak; C Sementasi pasak, D.Gambaran rontgen sementasi pasak; E. Gambaran radiografis konfirmasi pengambilan gutta percha (Sumber: Dokumentasi pribadi)

Tahap selanjutnya adalah preparasi untuk pembuatan mahkota all-porcelain. Restorasi pre endodontic build-up sekaligus digunakan sebagai core untuk pembuatan preparasi full crown. Preparasi mahkota diawali preparasi aksial dengan membuat guideline menggunakan bur bulat di bagian servikal dengan kedalaman setengah diameter bur. Preparasi permukaan labial dilakukan dengan menggunakan bur diamond silindris dengan membuat pedoman groove dengan kedalaman 1-1,5 $\mathrm{mm}$ dan preparasi mengikuti bentuk anatomi bagian labial. Pengurangan bagian proksimal dilakukan dengan menggunakan bur pointed tapered cylindrical. Bagian insisal dilakukan pengurangan sekitar 1- 1,5 mm dari tepi insisal dengan menggunakan bor straight diamond. Bagian palatal dipreparasi dengan bur dan mengikuti anatomi bidang palatal.

Preparasi bagian servikal dengan menggunakan bur round end tapered cylindrical mengelilingi gigi membentuk akhiran chamfer. Akhiran preparasi dengan bentuk chamfer dapat membentuk kontur yang sesuai anatomi dan memberikan ruangan yang cukup untuk ketebalan bahan. Selanjutnya seluruh sudut preparasi dihaluskan menggunakan fine finishing bur berbentuk round end tapered cylindrical. Setelah preparasi selesai, tahap selanjutnya 
adalah pencetakan dengan teknik double impression menggunakan bahan cetak elastomer agar diperoleh hasil cetakan yang akurat. Gigi dipasangkan retraction cord untuk memperoleh detail akhiran preparasi (Gambar 6A dan B).
Model kerja kemudian di cor dan dikirim ke laboratorium untuk dibuatkan mahkota porselen. Gigi kemudian dibuatkan mahkota sementara dengan menggunakan bahan mahkota sementara (Protemp 3M ESPE, USA) (Gambar 6C dan D).

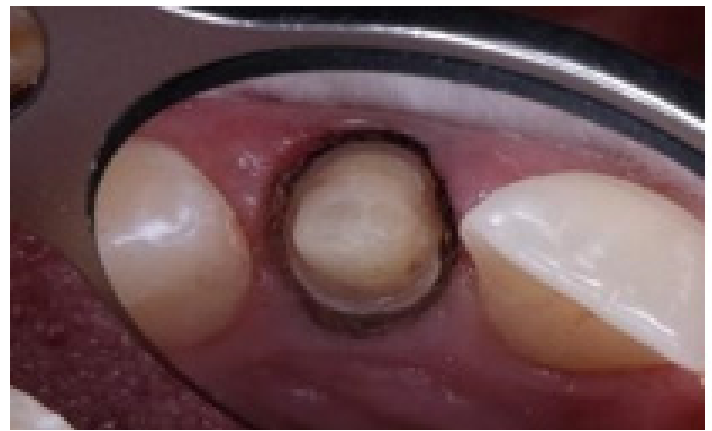

A

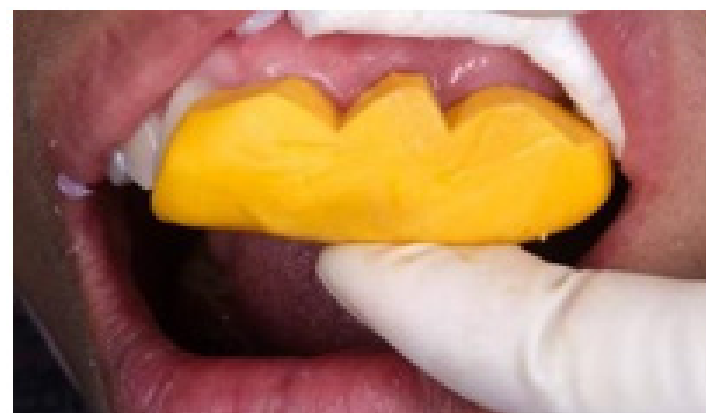

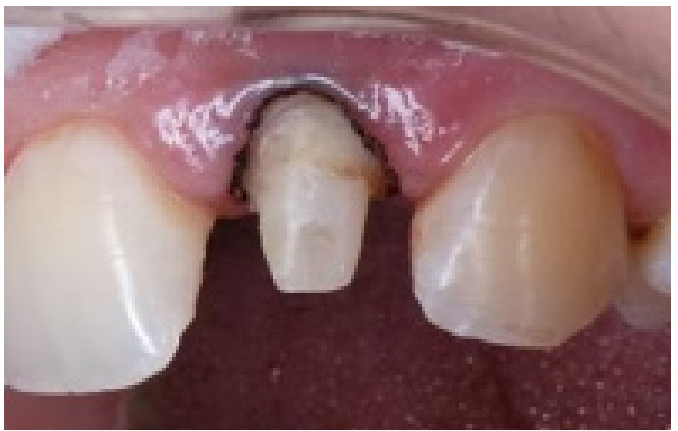

B

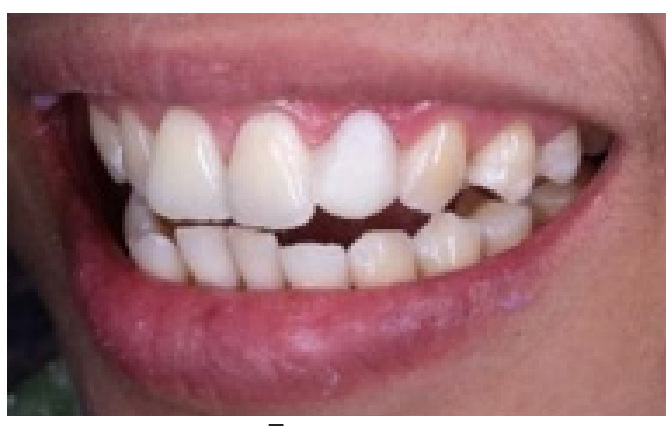

E

Gambar 6. Hasil preparasi pasak crown: A. Tampak dari incisal; B. Tampak dari labial; C. Pembuatan mahkota sementara dengan bantuan silicon index; D. Mahkota sementara telah terpasang (Sumber: Dokumentasi pribadi)

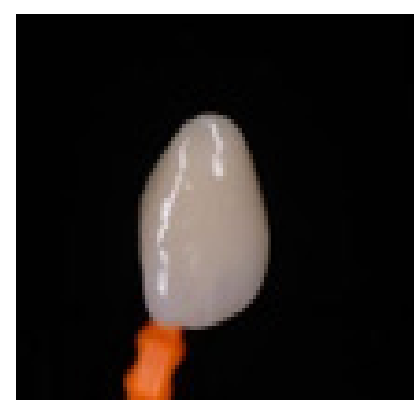

A

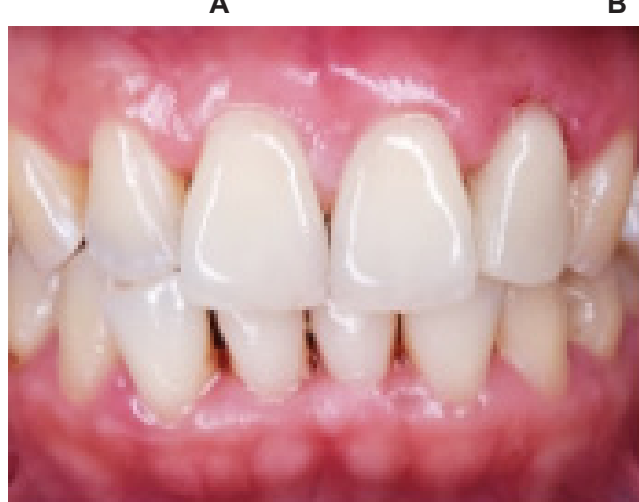

A

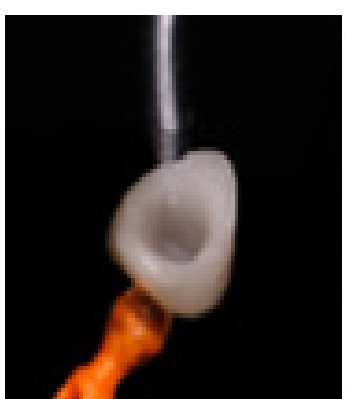

B

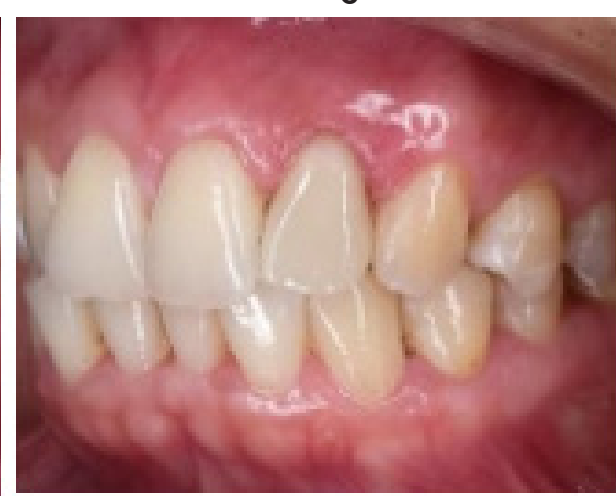

B

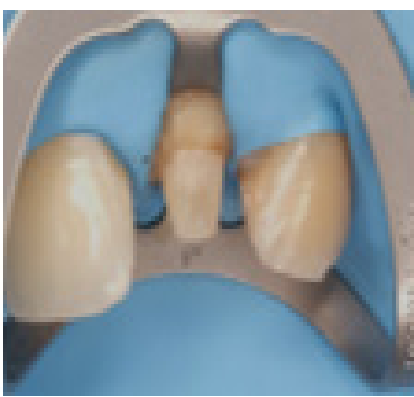

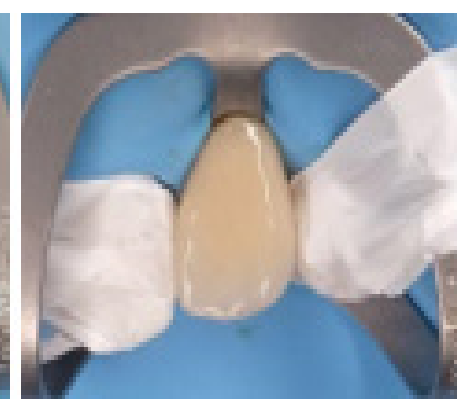

D

Gambar 7. Sementasi Mahkota All Porcelain e-max: A. Mahkota all porcelain e-max; B. Sunblasting dengan alumunium oksida; C. Isolasi dengan rubber dam; D. Sementasi dengan semen resin dual cure; E. Pengecekan oklusi, adaptasi proksimal dan akhiran restorasi; F. Konfirmasi radiologi pasca sementasi mahkota all porcelain emax (Sumber:

Dokumentasi pribadi) 
Satu minggu kemudian pasien datang untuk dilakukan pemasangan mahkota porselen dengan menggunakan semen resin dual cure (RelyX'M U200, 3M ESPE, USA). Dilakukan uji coba pemasangan mahkota porselen, diperiksa adaptasi, retensi akhiran preparasi, kontak proksimal dan oklusi. Sebelum dilakukan sementasi gigi dibersihkan dengan brush dan pasta poles, dibilas dan dikeringkan, kemudian diisolasi dengan rubber dam. Pada bagian dalam mahkota porselen dilakukan sandblasting dengan $30 \mu \mathrm{m}$ aluminium oksida, kemudian dibilas dan keringkan (Gambar 7B). Selanjutnya penyemenan dilakukan dengan menggunakan semen resin dual cure (RelyX ${ }^{\mathrm{TM}}$ U200, 3M ESPE, USA). Sisa semen yang berlebih dibersihkan dan kemudian dilakukan penyinaran selama 20 detik untuk pengerasan yang sempurna. Oklusi diperiksa kembali setelah melepas rubber dam dengan menggunakan articulating paper dan bagian proksimal dihaluskan dengan menggunakan polishing strip. Selanjutnya hasil sementasi dilakukan konfirmasi dengan foto radiografi (Gambar 7G).

Kontrol dilakukan dua minggu setelah pemasangan mahkota all porcelain emax. Hasil pemeriksaan: tidak terdapat keluhan subjektif pasien, tes perkusi, tekan dan palpasi negatif, tidak terdapat kegoyangan gigi dan kelainan pada jaringan lunak. Gigi dapat berfungsi dengan baik dan pasien merasa puas dengan hasil akhir perawatan. Pasien menandatangani lembar informed consent setelah mendapatkan penjelasan mengenai seluruh prosedur perawatan, memahami risiko, dan menyetujui rencana perawatan yang diberikan. Laporan kasus ini telah mendapatkan persetujuan dari pasien melalui informed consent yang diberikan.

\section{PEMBAHASAN}

Penggunaan rubber dam selama perawatan saluran akar sangat penting untuk mencegah kontaminasi bakteri, pasien terhindar dari tertelannyainstrumentmaupun bahan, perlindungan jaringan dari instrumen rotary, memberikan lapang pandang yang baik, dan melindungi operator dari infeksi silang yang dapat ditransmisikan melalui aerosol dan saliva pasien. ${ }^{7,8}$ Isolasi menggunakan rubber dam pada kasus dengan keadaan tertentu seperti kehilangan mahkota klinis atau kerusakan mahkota gigi yang sangat luas sehingga struktur yang tersisa sangat tipis/sedikit, pemasangan rubber dam menjadi sulit dan merupakan tantangan tersendiri bagi operator. Fraktur sebatas mahkota yang terjadi pada kasus ini diakibatkan karena gigi pasca perawatan saluran akar mempunyai sifat fisik yang berbeda dengan gigi vital. Keadaan pada gigi yang telah dilakukan perawatan saluran akar biasanya mengalami kehilangan struktur yang cukup banyak akibat karies, luasnya kerusakan, serta prosedur preparasi yang menyebabkan menurunnya kekuatan gigi sehingga menjadi rentan terhadap fraktur. ${ }^{10}$

Kehilangan mahkota yang sangat luas pada kasus ini terjadi akibat fraktur karena pasien sempat menunda perawatan saluran akar cukup lama dan tidak melanjutkannya. Keadaan gigi dengan sisa struktur mahkota yang sedikit dan tipis menyulitkan operator ketika pemasangan klem rubber dam untuk mengisolasi area kerja saat melakukan perawatan saluran akar. Penempatan klem pada sisa struktur jaringan keras yang tipis dan sedikit dapat mengakibatkan fraktur pada sisa jaringan, terlepasnya klem, menimbulkan trauma pada jaringan lunak saat penempatan klem, adanya kebocoran saliva maupun cairan gusi sehingga sulit mendapatkan hasil perawatan saluran akar yang memuaskan. ${ }^{1,2,3,4,5}$ Prosedur gingivektomi, pemanjangan mahkota (crown lengthening) merupakan beberapa cara yang dapat dilakukan untuk menempatkan klem rubber dam saat mengisolasi gigi dengan keadaan mahkota klinis yang sudah rusak parah. ${ }^{5}$ Kehilangan seluruh mahkota terutama gigi anterior seperti yang terjadi pada kasus ini, tidak dapat menyediakan estetik yang memadai serta memungkinkan terlepasnya tambalan sementara selama perawatan saluran akar sehingga dapat terjadi kebocoran medikamen antar kunjungan.

Kebocoran koronal salah satunya dapat disebabkan rusaknya restorasi sementara. Penutupan koronal yang baik sangat penting untuk melindungi gigi terhadap kontaminasi cairan rongga mulut, masuknya mikroorganisme dan mencegah infeksi ke dalam saluran akar selama perawatan antar kunjungan. ${ }^{7,8}$ Tujuan dari restorasi sementara yang dikutip dari Peters dan Noblett ${ }^{13}$ adalah: 1) sebagai segel koronal untuk mencegah masuknya cairan rongga mulut dan bakteri serta keluarnya medikamen intrakanal. 2) 
meningkatkan isolasi selama prosedur perawatan. 3) melindungi struktur gigi hingga restorasi akhir selesai dipasang. 4) mudah dalam penempatan dan pelepasan. 5) memenuhi estetik, akan tetapi sebagai pertimbangan sekunder dari fungsi utama yang memberikan seal. ${ }^{13}$ Johnson dan Williamson ${ }^{14}$ menyatakan apabila struktur gigi yang tersisa tidak terdapat retensi yang memadai untuk bahan restorasi sementara maka dapat dibuat coronal build-up untuk menggantikan struktur yang hilang. Kehilangan struktur mahkota yang parah pada gigi anterior rahang atas seperti pada kasus ini memerlukan build-up untuk menyediakan seal yang baik, memberikan perlindungan dan mencegah terjadinya kebocoran antar kunjungan, penggunaan isolasi dengan rubber dam yang atraumatik dan terutama dapat memberikan estetik yang baik. ${ }^{2}$

Pembuatan restorasi pre endodontic buildup dengan teknik canal projection pada kasus ini dengan kehilangan struktur koronal yang luas akan memudahkan proses pengerjaan perawatan saluran akar, mempertahankan canal patency atau bentuk saluran dari kamar pulpa hingga batas cavosurface dan menghasilkan coronal seal yang baik sehingga dapat mencegah coronal leakage selama perawatan saluran akar. ${ }^{1,2,3,4,5}$ Pre endodontic build-up awalnya dipelopori oleh Gerald N Glickmann dan Roberta Pillegi dengan alatnya yaitu Projector Endodontic Instrument Guidance System (PEIGS). 1,2,3,4,5 Teknik ini memproyeksikan saluran akar dari orifis lantai ruang pulpa hingga ke cavosurface, sehingga dapat meningkatkan visualisasi dan akses ke saluran akar. Teknik ini juga memberikan kemudahan dalam penempatan klem rubber dam sehingga dapat menghasilkan isolasi yang baik selama perawatan. .,2,3,4,5 $^{2}$ Peredaran alat PEIGS (CFN engineering, Santa Barbara CA) terbatas sehingga sulit didapatkan untuk penggunaannya. Pembuatan pre endodontic build-up dapat dilakukan dengan menggunakan teknik dan alat yang tersedia di klinik seperti jarum suntik, gutta percha dan tip plastik sekali pakai. 1,2,3,4,5 Restorasi sementara pre endodontic buildup dengan canal projection dalam laporan kasus ini dimodifikasi dengan menggunakan plastik tip sekali pakai dari Calcipex II (Nippon Shika Yakuhin Co., Ltd, Japan) yang tersedia di klinik. Teknik ini merupakan metode yang sederhana, murah dan efisien dapat dengan mudah dikerjakan dalam praktik klinis.
Bahan coronal build-up dapat menggunakan resin komposit, amalgam, maupun glass ionomer.1,3,4,5 Perbaikan estetika pada gigi anterior dengan kerusakan mahkota yang sangat luas seperti yang terjadi dalam kasus ini juga dapat teratasi dengan pembuatan restorasi pre endodontic build-up menggunakan bahan komposit selama perawatan saluran akar. ${ }^{2}$ Pasien pada laporan kasus ini berprofesi sebagai seorang tenaga pendidik mempunyai kebutuhan estetik yang cukup tinggi, sehingga kebutuhan akan mahkota sementara yang juga dapat memenuhi fungsi estetik.

Pembuatan pre endodontic build-up dapat menghasilkan penutupan yang baik sampai dasar kamar pulpa, memudahkan orientasi dan insersi instrumen rotary ke dalam saluran akar terutama pada kasus dengan kehilangan dentin yang dekat dengan orifis. Canal projection ini dapat mencegah masuknya bahan restorasi ke dalam saluran akar selama pembuatan pre endodontic build-up. ${ }^{1}$ Penempatan bahan komposit, GIC atau amalgam saat pembuatan pre endodontic build-up dapat menggunakan matriks, orthodontic band, atau mahkota sementara siap pakai. ${ }^{5}$ Pembuatan pre endodontic build-up pada kasus ini menggunakan bahan komposit dengan acuan bentuk gigi yang telah dibuat mock-up pada model studi. Pembuatan restorasi sementara pre endodontic ini dilakukan menggunakan matriks palatal dari bahan material double impression dengan tip plastik sekali pakai yang diletakkan dari orifis ke arah incisopalatal kemudian dilanjutkan dengan pembuatan bagian proksimal dan bagian labial. Metode ini memberikan kemudahan saat isolasi, penempatan klem rubber dam, memberikan seal yang adekuat, bentuk yang estetik, reservoir bagi larutan irigasi dan sebagai restorasi sementara yang sangat baik. .,2,3,4,5 $^{2}$

Pembuatan dan pemilihan restorasi pada gigi pasca perawatan saluran akar ditentukan oleh jumlah dan struktur gigi sehat yang tersisa. Kehilangan jaringan keras dalam jumlah besar setelah perawatan saluran akar menyebabkan gigi menjadi rentan terhadap fraktur. Restorasi pada gigi yang telah dirawat saluran akar harus dapat melindungi struktur gigi yang tersisa agar terhindar dari risiko fraktur. Menurut Dietschi dkk ${ }^{10}$ restorasi gigi pasca perawatan endodontik bertujuan untuk (1) melindungi struktur gigi yang tersisa dari fraktur, (2) mencegah terjadinya infeksi ulang pada sistem 
saluran akar, dan (3) mengganti struktur gigi yang hilang. Gigi anterior pasca perawatan saluran akar dengan kehilangan struktur yang sangat luas, yaitu kondisi struktur sehat yang tersisa kurang dari 50\% memerlukan restorasi akhir dengan menggunakan restorasi crown yang didukung oleh pasak dan inti. $^{10,12}$

Sisa jaringan sehat koronal pada kasus ini sangat minimal hampir seluruh mahkota hilang sehingga diperlukan pemasangan pasak dan restorasi akhir mahkota penuh. Pasak digunakan pada gigi yang telah dilakukan perawatan endodontik dengan struktur mahkota gigi yang tersisa kurang dari setengah atau hanya struktur akarnya saja yang tersisa. ${ }^{10}$ Pasak diperlukan untuk menambah retensi dan meneruskan tekanan yang diterima gigi merata ke sepanjang akar. ${ }^{15,16}$ Pasak fiber yang merupakan salah satu bahan dasar memiliki modulus elastisitas yang serupa dengan dentin, dapat menyerap tekanan dengan baik sehingga mampu mencegah terjadinya fraktur akar, dapat berikatan secara adhesif dengan dinding saluran akar, serta memiliki tampilan yang transparan sehingga memberikan estetik yang baik. ${ }^{15,16,17}$

Kelebihan lain pasak fiber tidak bersifat korosif, tidak menghantarkan panas secara berlebih, dan daya tahan terhadap fraktur akar yang lebih baik dibandingkan dengan pasak metal. Pasak fiber juga mudah diangkat kembali apabila terjadi kegagalan perawatan endodontik. ${ }^{10}$ Mahkota all-porcelain merupakan pilihan yang sangat tepat untuk meningkatkan hasil estetika terutama pada gigi anterior. Lithium disilicate merupakan jenis keramik yang banyak dipilih karena mempunyai kekuatan dan ketahanan fraktur serta kualitas estetik yang sangat baik sehingga dapat menyerupai tampilan gigi alami. ${ }^{18}$

\section{SIMPULAN}

Pembuatan restorasi sementara pre endodontic bulid up dengan teknik canal projection selama perawatan saluran akar berhasil dilakukan pada gigi insisif lateral kiri atas dengan kerusakan mahkota yang sangat luas. Pre endodontic bulid up dengan teknik canal projection pada kasus ini memberikan keberhasilan dalam pengerjaan perawatan saluran akar, menghasilkan coronal seal yang baik, isolasi yang memadai dengan kemudahan penempatan klem rubber dam serta memberikan pemulihan estetik yang baik dengan restorasi sementara dalam periode antar kunjungan.

\section{DAFTAR PUSTAKA}

1. Ahuja S, Bedi RPS, Garg A, Singh $H$. Restoration of a grossly carious tooth using canal projection: a comparative analysis of different materials for use as canal projectors. 2017;4(3):70-76.

2. Balasubramanian $S$, Ballal $V$, Acharya $S R$. Provisional pre-endodontic restoration of a badly broken down maxillary central incisor two case reports. Int J Maxillofac Res. 2015; 1(2):154-164.

3. Iftekhar $\mathrm{H}$. Endodontic management of badly broken down tooth with radix entomolaris using the canal projection technique. J Oral Res Rev. 2019;11(1):36-40. DOI: 10.4103/jorr.jorr

4. Gupta I, Gupta S, Ghosh S. Canal projection: restoring the past, building the future. 2017;2(8):8-10.

5. Tanikonda R, Canal projection using guttapercha points: A novel technique for preendodontic buildup of grossly destructed tooth. J Conserv Dent. 2016;19(2):194-197. DOI: 10.4103/0972-0707.178709

6. Amlani H. Microleakage: Apical Seal vs Coronal Seal. World J Dent. 2013; 4(2): 113-116.DOI: 10.5005/jp-journals-10015-1215

7. Ballal NV, Khandelwal D, Saraswathi MV. Rubber dam in endodontics: An overview of recent advances. Oral Pathol Oral Med. 2015; 6(4):317-28.

8. Hegde M, Hegde P, Hegde A. Rubber dam isolation for endodontic treatment in difficult clinical situations. Res Rev J Dent Sci RRJDS,. 2014;2(2):12-18.

9. Kanat-Ertürk B, Saridağ $S$, Köseler E, Helvacioğlu-Yiğit D, Avcu E, Yildiran-Avcu Y. Fracture strengths of endocrown restorations fabricated with different preparation depths and CAD/CAM materials. Dent Mater J. 2018; 37(2): 256-65. DOI: 10.4012/dmj.2017-035

10. Dietschi D, Bouillaguet S, Sadan A. Restoration of Endodontically Treated Tooth. In: Hargreaves KM, Berman LH, eds. Cohen's Pathways of the Pulp. $11^{\text {th }}$ ed. Elsevier; 2016. p. 818-48. DOI: 


\subsection{7/CBO9781107415324.004}

11. de Carvalho MA, Lazari PC, Gresnigt M, Del Bel Cury AA, Magne P. Current options concerning the endodontically-treated teeth restoration with the adhesive approach. Braz Oral Res. 2018;32(1):147-158. DOI: 10.1590/18073107bor-2018.vol32.0074

12. Pedrollo Lise D, Van Ende A, De Munck J, Umeda Suzuki TY, Cardoso Vieira LC, Van Meerbeek B. Biomechanical behavior of endodontically treated premolars using different preparation designs and CAD/CAM materials. J Dent. 2017;59:54-61. DOI: 10.1590/18073107bor-2018.vol32.0074

13. Peters OA, Noblett WC. Cleaning and shaping. In: Torabinejad $M$, Walton RE, Fouad $A F$, eds. Endodontics Principles and Practice. $5^{\text {th }}$ ed. Elsevier Saunders; 2015:273-300. DOI: 10.2307/486972.

14. Johnson WT, Williamson AE. Chapter 15: Isolation, Endodontic Access, And Length Determination. In: Torabinejad $M$, Walton
RE, Fouad AF. Endodontics: Principles and Practice. $5^{\text {th }}$ ed. Elsevier Saunders; 2015. p. 244-272.

15. Nicola S, Alberto F, Riccardo MT, et al. Effects of fiber-glass-reinforced composite restorations on fracture resistance and failure mode of endodontically treated molars. J Dent. 2016;53:82-7. DOI: 10.1016/j. jdent.2016.08.001

16. Bru E, Forner L, Llena C, Almenar A. Fibre post behaviour prediction factors. A review of the literature. J Clin Exp Dent. 2013; 5(3): 150-153. DOI: $10.4317 /$ jced. 50619

17. Mergulhão VA, De Mendonça LS, De Albuquerque MS, Braz R. Fracture resistance of endodontically treated maxillary premolars restored with different methods. Oper Dent. 2019; 44(1): E1-11. DOI: 10.2341/17-262-L

18. Willard A, Gabriel Chu TM. The science and application of IPS e.Max dental ceramic. Kaohsiung J Med Sci. 2018; 34(4): 238-242. DOI:10.1016/j.kjms.2018.01.012 